\title{
SEISMIC VULNERABILITY APPRAISAL ACCORDING TO THE ALGERIAN BUILDING CONTEXT
}

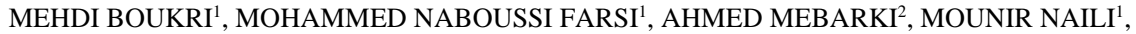 \\ MOHAMED BELAZOUGUI ${ }^{1}$, OMAR AMELLAL ${ }^{3}$, NABILA GUESSOUM ${ }^{1}$ \& BRAHIM MEZAZIGH $^{4}$ \\ ${ }^{1}$ National Earthquake Engineering Research Centre, Algeria \\ ${ }^{2}$ University Paris-Est, Laboratoire Modélisation et Simulation Multi Echelle, France \\ ${ }^{3}$ University of Blida 1 , Algeria \\ ${ }^{4}$ University of Boumerdès, Algeria
}

\begin{abstract}
This contribution focuses on the adaptation and application of RADIUS methodology (Risk Assessment Tools for Diagnosis of Urban Areas Against Seismic Disaster) integrated with a Geographic Information System (GIS) to the Algerian context for the seismic vulnerability evaluation in urban areas potentially exposed to earthquakes. Within this framework, this application aims to perform a probable earthquake scenario in the urban centre of Constantine city, located at the North-East of Algeria, which will allow the buildings seismic damage estimation of this city. For that, an extensive inventory of almost 31,000 buildings was carried out. The simulation of the expected building seismic damage and the generated GIS damage maps provides a predictive evaluation of the damage that can occur due to a potential earthquake near to Constantine city.The theoretical forecasts are considered important for decision makers in order to reduce building vulnerability, to take adequate preventive measures and to develop suitable strategies for prevention and emergency management plans to reduce the losses. They can also help to identify the most damaged areas in the early moments following an earthquake to take the adequate emergency measures.
\end{abstract}

Keywords: seismic vulnerability, Algerian building, RADIUS, earthquake scenario, Constantine.

\section{INTRODUCTION}

During the last decades, the seismic risk to which the urban areas are exposed became a world concern because of the potential losses in human lives as well as in infrastructures that can occur following a major earthquake. A co-operation on a worldwide scale is necessary for an exchange of information and experiments for prevention and installation of action plans in countries prone to this phenomenon.

Algeria is one of the countries where the seismic activity is significant [1] and concerns mainly the Northern part of the country where the greatest urban cities are located and where seismic risk continues growing with the development of the economic fabric and the growth of population. To protect those cities against this seismic risk is critical initially to try to understand and to evaluate the situation which will occur after the phenomenon occurrence.

For that, it proves necessary to develop seismic risk mitigation strategies, to employ tools for analysis and to lead actions for a successful prevention of the effects of this natural phenomenon. However, the seismic risk assessment on the urban scale proves to be a complex task, which requires a multidisciplinary interaction in order to evaluate the physical damage caused with the exposures, number and type of victims or economic losses [2], as well as with the social, organisational and institutional vulnerability.

It is then required to adopt and simulate potential earthquake scenarios [3] that may affect an urban area and its surroundings, which will allow to have a first idea on the spatial distribution of the damage and their extent, and to elaborate an action plan to confine the human and economic losses to their minimal level [1].

During the 1990s, loss assessment models saw a significant and fast development [4], following several storms in Europe, the Andrew hurricane in 1992, the Northridge earthquake 
in 1994 (USA) and that of Kobe in Japan in 1995, which caused catastrophic losses to the world insurers and reinsurers who then recognized the utility of such models. Indeed, those loss assessment models allow a better quantification of the risks than they cover and thus a better knowledge of their exposure.

In Algeria, several studies were carried out in the field of the vulnerability and seismic risk assessment, more particularly we can quote: the study of vulnerability of DJELFA city in 1985, Preliminary evaluation of the Algiers seismic risk in 1986 [5], Seismic risk assessment of current buildings of Algiers city [6], Study of seismic microzoning of the Wilaya of Algiers in the People's Democratic Republic of Algeria [7].

Under the aegis of the United Nations, the secretariat of the International Decade for the Natural Disaster Reduction (IDNDR) launched in 1996 the seismic damage assessment project RADIUS (Risk Assessment Tools for Diagnosis of Urban Areas against Seismic Disasters) for developing countries with technical and financial support of the Japanese Government [8], and with the assistance of Geo-Hazard International (GHI) in the United States.

The application of the RADIUS methodology to the case of Algerian urban areas comes owing to the fact that building typologies are similar to those adopted by this method. Also, Algiers capital city belonged to the 58 cities proposed initially for the realization of earthquake scenarios with the proposal of adequate risk management plans, before retaining only nine cities, namely: Addis-Abeba (Ethiopia), Antofagasta (Chile), Bandung (Indonesia), Guayaquil (Ecuador), Izmir (Turkey), Skopje (Macedonia), Tashkent (Ouzbekistan), Tijuana (Mexico) and Zigong (China) [9].

The main point for using RADIUS methodology to the case of Algerian urban areas comes owing to the fact that it proves to be simple of use and adaptable to the Algerian context, since the building typologies are similar to those adopted by this method.

Within this framework, the urban centre of Constantine city, located in an active seismic zone in Algeria, has been taken as example of application by using this methodology with its adaptation for the urban seismic risk assessment according to the Algerian context.

\section{METHODOLOGY PROCESS}

RADIUS Methodology is articulated around the four (04) main steps presented in Fig. 1 [9]:

- Evaluation of the seismic risk and its spatial distribution, on regional and local scale as well as of the soil conditions;

- Analysis of the urban system and identification of the essential elements (human, physical, functional, etc.) exposed to the risk;

- Analysis of vulnerability (vulnerability functions);

- Evaluation of the selected earthquake impact (seismic risk or overall human and material losses and distribution by urban subdivisions).

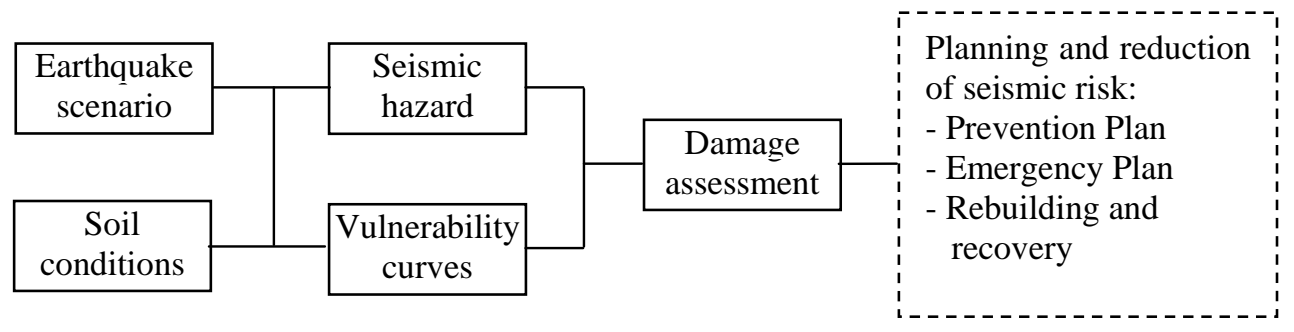

Figure 1: Earthquake scenario Plan of RADIUS [9]. 
The RADIUS tool introduces a simplified method in order to subdivide the study area by mesh units. Mesh spacing from $500 \mathrm{~m}$ to $5 \mathrm{~km}$ is proposed, because the main objective is the description of the city and its extent. The zoning of the city can also be performed by districts or sectors of irregular area forms requiring the use of a Geographical Information System (GIS). More the zoning is refined, the results are more detailed. Thus, the damage assessment is performed for each unit of the study area considered.

Earthquake scenarios can be proposed in the urban areas to allow estimating earthquake extent and consequences likely to occur, property damages and human life losses.

The scenario is to show how the situation would develop from the point of view of the damage caused to buildings, infrastructures and population in each district or sector of the urban area affected for the period following the earthquake.

\subsection{Seismic hazard}

The RADIUS model uses a very popularly worldwide intensity scale, namely the MMI (Modified Mercalli Intensity) scale. It is defined by the conversion of Peak Ground Acceleration (PGA) by using the empirical formula of Trifunac and Brady [9] (as in eqn 1).

$$
M M I=1 / 0.3 x\left[\log _{10}(P G A x 980)-0.014\right]
$$

The Peak Ground Acceleration (PGA) can be calculated by using one of the three attenuation laws defined in RADIUS, namely: Joyner and Boore [10], Campbell [11] or Fukushima and Tanaka [12], as illustrated in Table 1.

\subsection{Soil conditions}

RADIUS model adopts four ground classifications based on the surface soil, namely, "Hard Rock", "Soft Rock", "Medium Soil" and "Soft Soil". In addition, a user may choose "Unknown" if the soil conditions are not known [9]. This classification corresponds to that established by the Algerian building code [13]. An amplification factor corresponds to each soil type, an as shown in Fig. 2.

\subsection{Building damage estimation}

The classification adopted by the RADIUS model (see Table 2) was established for the ten (10) most representative building types in the majority of the Latin America countries and in other similar areas in the world [8], [9].The classification is based on parameters which narrowly correspond to the observed damage at the time of the past earthquakes. An adaptation of this classification was made for its use to the Algerian building context where the first building code was issued in 1981 [14].

Table 1: Attenuation laws used by RADIUS [9].

\begin{tabular}{|l|l|}
\hline \multicolumn{1}{|c|}{ Source } & \multicolumn{1}{c|}{ Attenuation Law } \\
\hline \multirow{2}{*}{ Joyner \& Boore [10] } & $\mathrm{PGA}=10^{\wedge}\left(0.249^{*} \mathrm{M}-\mathrm{Log}(\mathrm{D})-0.00255^{*} \mathrm{D}-1.02\right.$, \\
& $\mathrm{D}=\left(\mathrm{E}^{\wedge} 2+7.3^{\wedge} 2\right)^{\wedge} 0.5$ \\
\hline \multirow{2}{*}{ Campbell [11] } & $\mathrm{PGA}=0.0185^{*} \mathrm{EXP}\left(1.28^{*} \mathrm{M}\right) * \mathrm{D}^{\wedge}(-1.75)$, \\
& $\mathrm{D}=\mathrm{E}+0.147^{*} \mathrm{EXP}\left(0.732^{*} \mathrm{M}\right)$ \\
\hline \multirow{2}{*}{ Fukushima \& Tanaka [12] } & $\mathrm{PGA}=\left(10^{\wedge}\left(0.41^{*} \mathrm{M}-\mathrm{LOG} 10\left(\mathrm{R}+0.032^{*} 10^{\wedge}\left(0.41^{*} \mathrm{M}\right)\right)-\right.\right.$ \\
\hline \multicolumn{2}{|c|}{ E: Epicentral Distance $; \mathrm{R}:$ Hypocentral Distance } \\
\hline
\end{tabular}




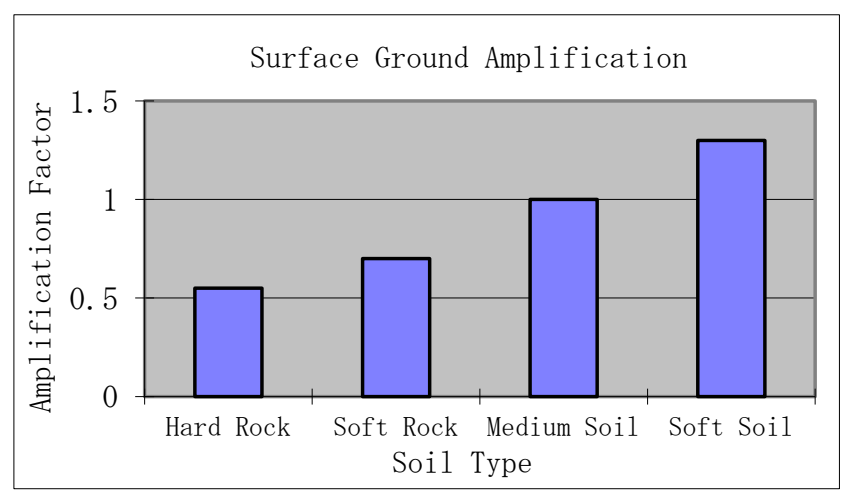

Figure 2: Soil amplification conditions [9].

Table 2: Building vulnerability classes according to Radius model.

\begin{tabular}{|l|l|}
\hline $\begin{array}{l}\text { Building } \\
\text { Type }\end{array}$ & \multicolumn{1}{c|}{ Definition } \\
\hline RES1 & Informal constructions. \\
\hline RES2 & $\begin{array}{l}\text { URM/RC Constructions not complying to any building code (and of which } \\
\text { the number of stories is up to 3. }\end{array}$ \\
\hline RES3 & $\begin{array}{l}\text { URM/RC Constructions not complying to any building code and of which } \\
\text { the number of stories is more than 3. }\end{array}$ \\
\hline RES4 & RC Construction newly constructed multi-story buildings \\
\hline EDU1 & School and office buildings, up to 2 stories. \\
\hline EDU2 & School and office buildings, greater than 2 stories. \\
\hline MED1 & Low to medium-rise hospitals. \\
\hline MED2 & High-rise hospitals. \\
\hline COM & Shopping centres. \\
\hline IND & Industrial facilities: both low and high-risk \\
\hline
\end{tabular}

The parameters are as follows: building materials, construction system, applied code, building age, usage and number of stories. Moreover, the classification considers that the tools will mainly be used in developing countries. An adaptation of the classification was made to use it taking into account the Algerian building context. The classes or typologies are defined in Table 2.

Each type of construction is defined by a vulnerability function (see Fig. 3), which expresses the correlation between a characteristic parameter of the earthquake (intensity, acceleration, etc.) and the damage rate defined as the ratio of the repair costs and the replacement cost of the building. The vulnerability functions (curves) used by RADIUS are based on the experiment drawn from past earthquakes. 


\section{APPLICATION}

This application consists of performing an earthquake scenario in the urban area of Constantine city (see Fig. 4), located at the North-East of Algeria [15], which will allow the building seismic damage assessment of this city. For that, an extensive inventory of almost 31000 building units was carried out by the National Earthquake Engineering Research Centre (CGS), within the framework of the study of vulnerability and evaluation of the seismic risk of this city. The distribution of the buildings was digitized in a data base which comprises their technical information by using a Geographical Information system (GIS). Subsequently, the buildings were classified according to the RADIUS methodology (see Table 2). To have more precise results, the study area was subdivided into meshes of $0.5 \mathrm{~km}$ on the side (the smallest spacing proposed by RADIUS model) and areas of which each one contains a group of meshes.

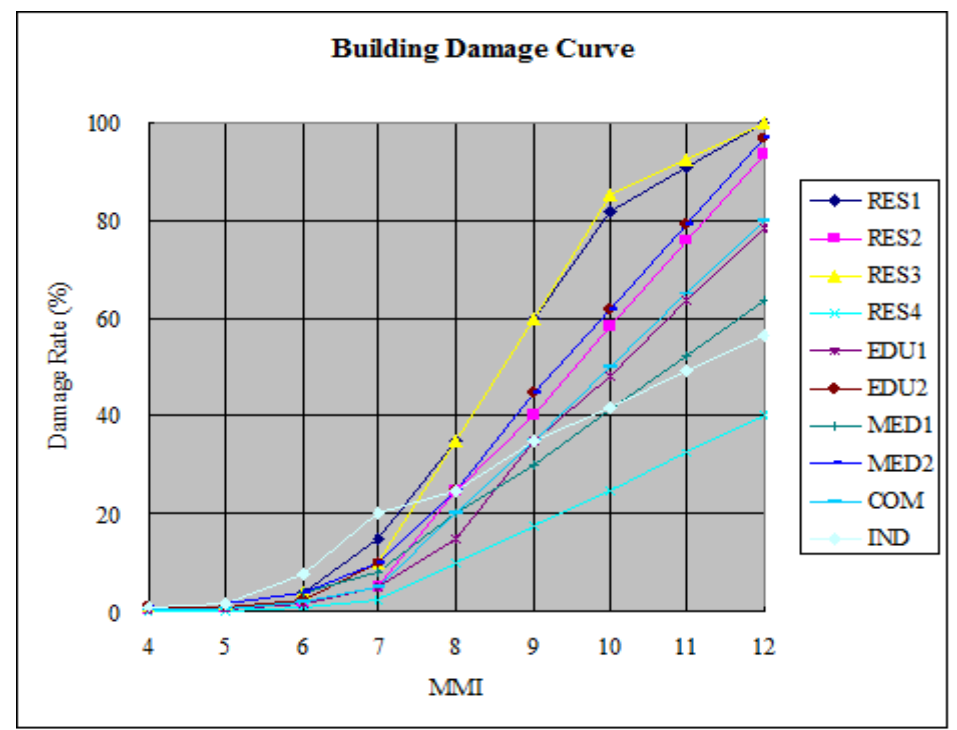

Figure 3: Vulnerability curves of different building classes [9].

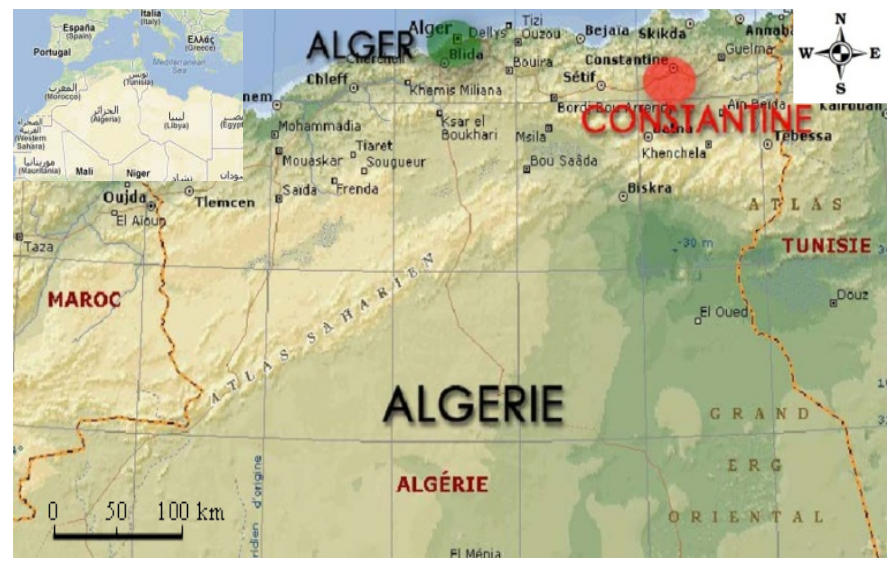

Figure 4: Location of Constantine city in Algeria [15]. 


\subsection{Seismic hazard}

The study of "Regional seismic hazard of Constantine region" [16], shows that Constantine city is surrounded by four (4) seismic sources which are active and can generate more or less significant earthquakes (see Table 3 ).

\subsection{Soil models}

The Soil Models of Constantine city were developed for each mesh on the basis of geotechnics and the geological investigation carried out by the National Earthquake Engineering Research Center [17], as well as on the basis of a geophysical study compiled and analysed, also supported by the identification campaigns of the landslide zones carried out within the framework of the seismic micro-zonation study of the urban sites of the Wilaya (Department) of Constantine, as shown in Fig. 5.

Table 3: Active faults conditions of Constantine region [15], [16].

\begin{tabular}{|c|c|c|c|}
\hline Fault & Dip ( ${ }^{\circ}$ ) & Mechanism & Magnitudes (Mw) \\
\hline Ain Smara (F1) & $\begin{array}{c}85^{\circ} \text { towards SE } \\
75^{\circ} \text { towards SE }\end{array}$ & $\begin{array}{c}\text { Strike-Slip } \\
\text { faulting }\end{array}$ & $7 \pm 0.23$ \\
\hline $\begin{array}{c}\text { Front de nappes } \\
\text { (F2) }\end{array}$ & $\begin{array}{c}70^{\circ} \text { towards NW } \\
80^{\circ} \text { towards NW }\end{array}$ & Reverse fault & $7 \pm 0.25$ \\
\hline Temlouka (F3) & $\begin{array}{c}65^{\circ} \text { towards NW } \\
75^{\circ} \text { towards NW }\end{array}$ & $\begin{array}{c}\text { Strike-Slip } \\
\text { faulting }\end{array}$ & $6.4 \pm 0.23$ \\
\hline Sigus (F4) & -- & Reverse fault & $7 \pm 0.25$ \\
\hline
\end{tabular}

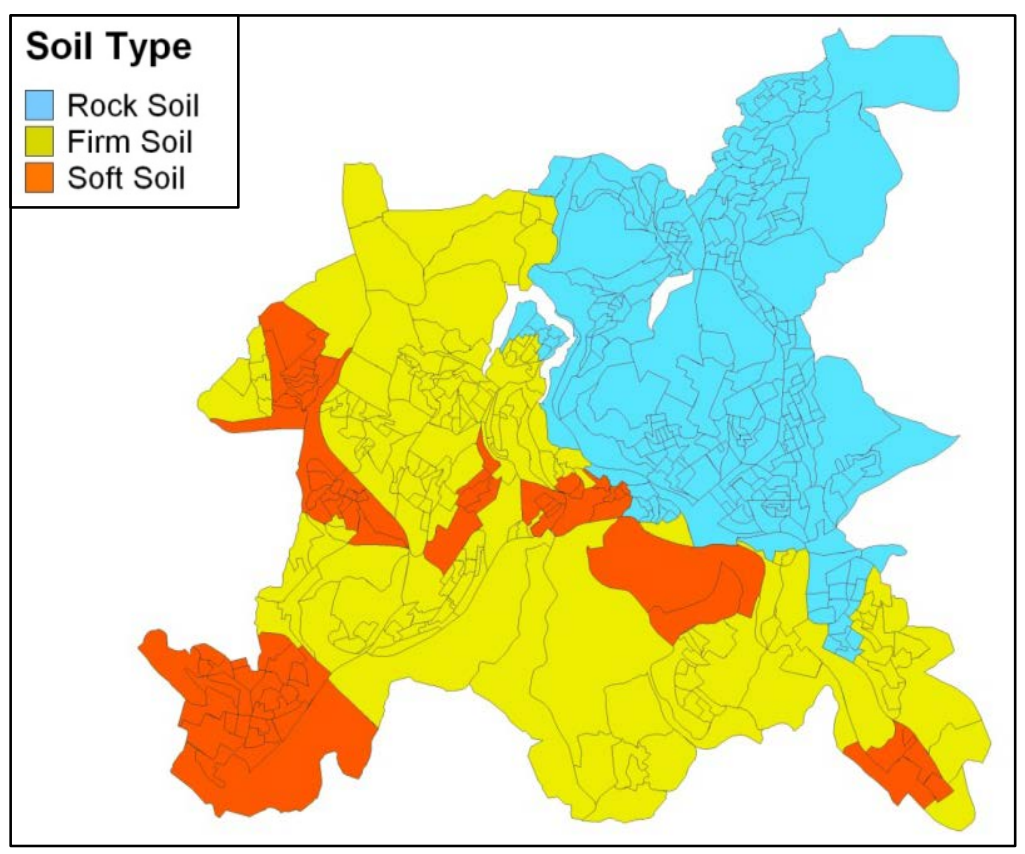

Figure 5: Soil classification of the study area by mesh [17]. 


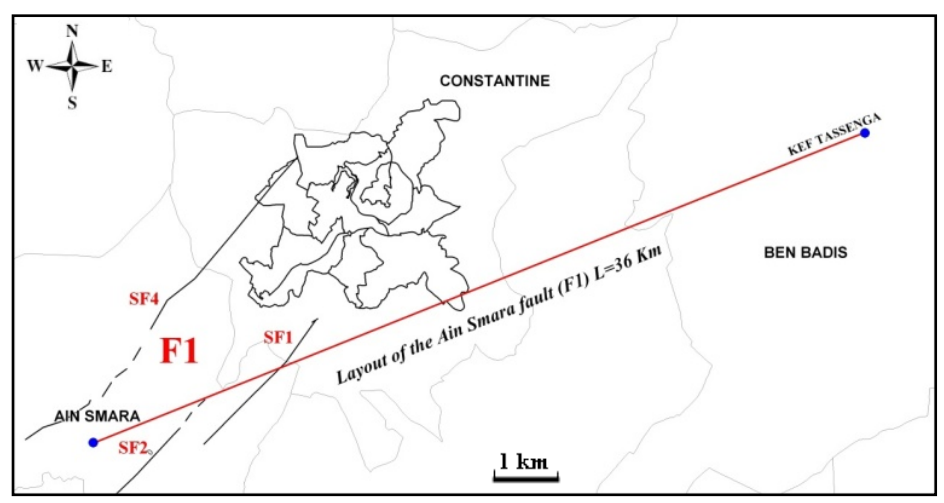

Figure 6: Representation of Ain-Smara fault compared to the study area - S: Fault Segment [15].

\subsection{Scenario earthquake}

According to the seismic hazard study discussed previously, the nearest fault which can affect more Constantine city is that of Ain Smara [12]. So, to perform the Earthquake Scenario in Constantine city, we have considered this fault for seismic modelling (earthquake scenario) (see Fig. 6).

This model is characterized by the following parameters:

- Ain Smara fault; Magnitude Mw = 7; 10 km of depth; Epicentral Distance: 1 Km; Dip:SE; Attenuation law: Joyner and Boore [10].

- Time of occurrence: the Radius tool proposes 2 horary portions for the casualties' estimation. That of the day is spread out between (6h-18h) and that of night (18h-6h) [9].

\subsection{Building damage estimation}

The building damage assessment is given for the Ten (10) sectors of Constantine city gathering the 228 meshes (see Table 2).The spatial distribution of the damage on the GIS urban map is illustrated for each mesh and urban subdivision (see Table 4 and Fig. 7).

Table 4: Mean damage rate by areas in Constantine city.

\begin{tabular}{|l|c|c|}
\hline Sector & Number of buildings & Damage ratio (\%) \\
\hline Old city & 4626 & 33.2 \\
\hline El Mansourah-SMK & 4237 & 15.3 \\
\hline Industrial Zone & 596 & 27.9 \\
\hline Martyrs & 6885 & 29.5 \\
\hline Daksi & 2938 & 18.8 \\
\hline Sidi M'cid & 928 & 16.9 \\
\hline Gammas & 4715 & 17.9 \\
\hline Djebel el Ouahch & 2628 & 12.7 \\
\hline University & 346 & 26.6 \\
\hline Boussouf & 2807 & 24.6 \\
\hline All the city & $\mathbf{3 0 7 0 6}$ & $\mathbf{2 3 . 0}$ \\
\hline
\end{tabular}




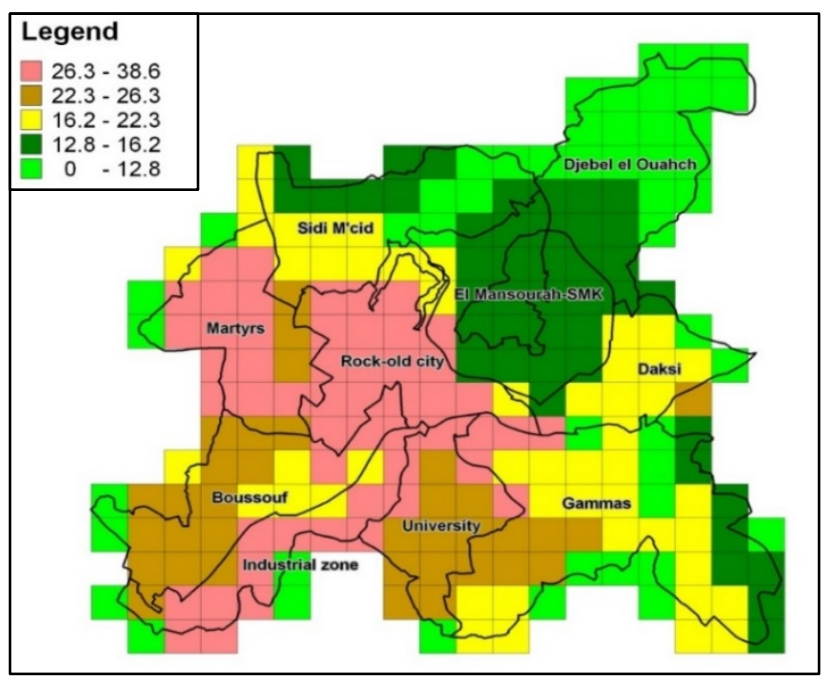

Figure 7: Damage ratio by meshes and sectors in Constantine city.

\section{CONCLUSION}

In this work, we have presented the adaptation of the RADIUS model to the urban seismic risk assessment in Algeria. The main point for using this methodology is that it proves to be simple of use and adaptable to the Algerian context.

To this end, we have applied it to realise an earthquake-scenario study in the urban area of Constantine city that contains 30706 constructions. That enabled us to calculate the distribution of the seismic intensity, the ground acceleration as well as the building damage in each mesh and sector of the city. The assumption was made of an earthquake of magnitude $\mathrm{Mw}=7$ generated from the Ain-Smara fault, which is closest to and more threatening for the study area.

The results of this earthquake scenario in Constantine city emphasize that the total rate of expected damage borders $23 \%$ and reaches the rate of $38 \%$ in some meshes. The highest damage concentrates primarily in the old city and Martyrs areas, where there is a concentration of the old buildings with a great percentage of precarious constructions. The areas of the University and the Industrial Zone also present a likely percentage of significant damage to the buildings in them. In the same way, we have obtained results for the Boussouf area, which contains a significant number of residential buildings of all classes as well as school institutions and industrial facilities. This variety of buildings in the area is located on unstable soils with risk of landslides at some places. These factors worsen the buildings vulnerability to a likely major earthquake. The other areas of the city present a less probability of damage.

This seismic damage simulation procedure of buildings and the GIS damage maps generated provide a predictive assessment of the expected damage in case of the occurrence of a potential earthquake near to Constantine city.

These theoretical forecasts are significant for the development of suitable emergency management plan. They can also be useful for the authorities in the first hours post seismic event in order to concentrate the principal efforts to the potentially most affected areas. 


\section{REFERENCES}

[1] Boukri, M., Farsi, M.N., Mébarki, A. \& Belazougui, M., Development of an integrated approach for Algerian building seismic damage assessment. Structural Engineering and Mechanics, 47(4), Techno Press, pp. 471-493, 2013.

[2] Barbat, A.H., Lagomarsino, S. \& Pujades, L.G., Vulnerability Assessment of Dwelling Buildings. Chapter 6, Assessing and Managing Earthquake Risk, Springer, 2006.

[3] Veludo, I., Teves-Costa, P. \& Bard, P.Y., Damage seismic scenarios for Angrado Heroismo, Azores (Portugal). Bulletin of Earthquake Engineering, Springer, 11, pp. 423-453, 2003.

[4] Clark, K., The use of computer modelling in estimating and managing future catastrophe losses. The Geneva Papers on Risk and Insurance, 27(2), 15 pp., 2002.

[5] Tebal, F., Preliminary Evaluation of the Algiers seismic risk. Proceedings of the Regional Conference on Earthquake Engineering design, Casablanca, Morocco, 1986.

[6] Belazougui, M., Farsi, M.N., Remas, A., Bensaibi, M. \& Mezazigh, B., Seismic risk assessment of current buildings of Algiers city. Proceedings of the $13^{\text {th }}$ World Conference on Earthquake Engineering, Vancouver, Canada, 2004.

[7] OYO Corporation and National Earthquake Engineering Research Center, Algeria. Study of seismic microzoning of the Wilaya of Algiers in the People's Democratic Republic of Algeria, Final report, Algiers, Algeria, 2006.

[8] Okasaki, K. \& Radius Team, Radius Initiative for IDNDR-How to Reduce Urban Seismic Risk. Proceedings of the $12^{\text {th }}$ World Conference on Earthquake Engineering, Auckland, New Zealand, 2000.

[9] OYO Corporation, RADIUS Methodology, Report IDNDR, 2000.

[10] Joyner, W.B. \& Boore, D.M., Peak horizontal acceleration and velocity from strongmotion records including records from the 1979 Imperial Valley, California, earthquake. Bulletin of the Seismological Society of America, 71, pp. 2011-2038, 1981.

[11] Campbell, K.W., Near-source attenuation of peak horizontal acceleration, Bulletin of the Seismological Society of America, 71, pp. 2039-2070, 1981.

[12] Fukushima, Y. \& Tanaka, T., A new attenuation relation for peak horizontal acceleration of strong earthquake ground motion in Japan. Bulletin of the Seismological Society of America, 80, pp. 757-783, 1990.

[13] Ministry of Housing and Urban Planning, Algerian Seismic Code, RPA99/2003, DTRBC 2.48, Algeria, 2004.

[14] Ministry of Housing and Urban Planning, Algerian Seismic Code, RPA81, Algeria, 1981.

[15] Boukri, M. et al., Seismic risk and damage prediction: case of the buildings in Constantine city (Algeria). Bulletin of Earthquake Engineering, Springer, 12(6), pp. 2683-2704, 2014,

[16] National Earthquake Engineering Research Center, CGS, Seismic Hazard Study of Urban Areas in Constantine City, Report, Algeria, 2011.

[17] National Earthquake Engineering Research Center, CGS, Seismic Microzoning Study of Urban Areas in Constantine City, Report, Algeria, 2011. 